\title{
THE ONE INCORRUPTIBLE STILL POINT: A REVIEW OF THOMAS PYNCHON'S BLEEDING EDGE
}

When did Thomas Pynchon become a Jewish mother? The best available evidence suggests sometime around 1999. In that year, America's great postmodern novelist wrote a five-hundred-word article called "Hallowe'en? Over Already?" for the newsletter of his son's Manhattan school, The Cathedral

School. Pynchon describes attending a picnic, "a small miracle of easy-going and spontaneous community," and (with his son and "a small bunch of other kids") touring the Cathedral Church of St. John the Divine.

On the evidence of this short essay, as well as his eighth novel, Bleeding Edge (Penguin, 2013), Pynchon might need to be counted-along with Cormac McCarthy-among a set of macho postmodern men who have slightly mellowed with late fatherhood. When put alongside his 2009 novel, Inherent Vice, which this latest effort very much resembles, Bleeding Edge may evince a new, late Pynchon style: less about impersonal systems, more about individual characters; less difficult at the level of the sentence, more conventional in its storytelling style; less concerned with global plots, more with local communities. In short, the author usually associated with apocalypse delivered from above, and with sweeping historical metafiction, has taken a domestic turn. The results are fun and bracing.

Bleeding Edge tells the story of Maxine Tarnow, former Certified Fraud Examiner ( $\mathrm{CFE}$ ), Upper West Side almost-single Jewish mom raising two boys, Ziggy and Otis. Maxine is a slightly more responsible version of Doc Sportello, the stoner private dick of Inherent Vice. Though she's less of a pothead than her counterpart, Maxine won't hesitate to bend the rules when faced with a "no-brainer of a choice between friendship and super-picky guideline adherence." While many of her former CFE colleagues imagine themselves to be "the one incorruptible still point in the whole jittery mess," Maxine knows that justice sometimes requires going rogue. Screw the "super-picky" ACFE Code of Conduct! When another mother at her kids' school asks her to investigate one of her husband's business associates, Maxine uses her considerable powers of detection to follow a trail of fraud and corruption, finding that all paths lead to the menacing tech entrepreneur Gabriel Ice, CEO of the mysterious company hashslingrz, the last man stand- 
ing in Silicon Alley after the 2000 dot-com bust. Ice may be part of a conspiracy involving Russian mobsters, jihadists, time-traveling child soldiers, unnamed agencies of the U.S. government, and stock manipulators.

Bleeding Edge is also Pynchon's first sustained statement on the terrorist attacks of September 11, 2001. In 2002, Pynchon is alleged to have given an interview with Playboy Japan in which he said, "bin Laden may not even exist." Some doubt the authenticity of this interview, but whether or not it's real, the controversy over its veracity fits perfectly in the canon of Pynchon legends, such as claims that he was William Gaddis or J.D. Salinger, or the debunked allegation that he wrote letters to the Anderson Valley Advertiser under the pseudonym Wanda Tinansky. Those expecting a full-blown response to the terrorist attacks from Bleeding Edge may be disappointed, not least for its flirtation with theories that $9 / 11$ was a so-called false-flag operation, an inside job. These truther whispers largely arrive through the character of March Kelleher, Gabriel Ice's mother-in-law, who publishes her insinuations on her new-fangled "Weblog."

It quickly becomes clear that the clatter of official or even secret history is secondary to Pynchon's loving, painstaking reconstruction of the mood of the island of Manhattan during the long cultural pause extending from the end of the dot-com crash through the terrorist attacks of 20o1. Pynchon scrupulously evokes period detail with rapid-fire references to the mania for Jennifer Aniston's hair, Beanie Baby asset bubbles, Razor scooters, Britney Spears at the height of her artistic powers, Zima (already a nostalgia product by 2001), Pokémon, Monica Lewinsky, "LexisNexis, HotBot, AltaVista," a "gigantic 17-inch LCD monitor," Final Fantasy X, and on and on. None of this comes across as researched or forced. It feels instead as if Pynchon, while walking his son to school, was observing the humming life around him at the fin de siècle and taking extremely detailed mental notes.

While Pynchon's prose has undeniably loosened up, it hasn't lost what makes it distinctive: its lopsided cadence, its tendency to operate through the accretion of factoids-or, more precisely, the accretion of memorable (often proper) nouns. To wit, here's a description of the "drywall palimpsest" of Maxine's office building, which across the years has accommodated "wayward schoolkids, hash-pipe dreamers, talent agents, chiropractors, illegal piecework mills, mini-warehouses for who knows what varieties of contraband ... a dating service called Yenta Expresso, the In 'n' Out Travel Agency, the fragrant suite of acupuncturist and herb specialist Dr. Ying, and down 
the hall at the very end the Vacancy, formerly Packages Unlimited, seldom visited even when it was occupied."

Even as he rigorously catalogs everything around him, Pynchon dramatizes the attempt to resist what comes to be called in the novel "the indexed world," the commodification of the utopia the Internet briefly seemed to be at the end of the bloody twentieth century. Indeed, Pynchon occasionally resists his own indexing tendencies at the level of the sentence. For every passage in which Pynchon barrages us with nouns, Bleeding Edge offers countervailing narrative moments of grace. Take, for instance, this quiet, lovely passage:

Next day, evening rush hour, it's just starting to rain... sometimes she can't resist, she needs to be out in the street. What might only be a simple point on the workday cycle, a reconvergence of what the day scattered as Sappho said someplace back in some college course, Maxine forgets, becomes a million pedestrian dramas, each one charged with mystery, more intense than highbarometer daylight can ever allow. Everything changes. There's that clean, rained-on smell. The traffic noise gets liquefied. Reflections from the street into the windows of city buses fill the bus interiors with unreadable 3-D images, as surface unaccountably transforms into volume. Average pushy Manhattan schmucks crowding the sidewalks also pick up some depth, some purposethey smile, they slow down, even with a cellular phone stuck in their ear they are more apt to be singing to somebody than yakking. Some are observed taking houseplants for walks in the rain. Even the lightest umbrella-to-umbrella contact can be erotic.

Who else, among living American writers, can write passages as beautiful as this? Pynchon exhibits his highest artistry, for my money, in the aesthetic friction between the stream of his commodified, secular nouns and the utopian transcendence offered up in an image of someone taking his houseplant for a walk (what a perfect detail!).

Bleeding Edge is able to find grounds for hope in the historical moment of the early 2000 s among dot-com refugees, not because Pynchon loves dotcom capitalists, but because the popularity of such entrepreneurial figures gives evidence that we've not yet lost our capacity to dream of better tomor- 
rows. The great world-historical conflict Pynchon cares most passionately about, in this book at least, isn't the Global War on Terror but the endless war between nerds and jocks (we know which camp he counts himself in). At the end of the 1990s, with the rise of the so-called New Economy, it briefly seemed as if nerds might gain the upper hand, but the stock crash soon put the kibosh on any such illusions: "The jocks may not know a stochastic crossover if it bites them on the ass, but they have that drive to thrive, they're synced in to them deep market rhythms, and that'll always beat out nerditude no matter how smart it gets," Pynchon writes.

This jock-nerd war makes its way to DeepArcher, a virtual world, hidden in the Dark Web (that part of the Internet invisible to Web crawlers), created by another pair of entrepreneurs with whom Maxine is acquainted. DeepArcher is Pynchon's most interesting creation in this book, partly because it inspires his most dreamy prose, partly because it shows how he has come to be influenced by those whom he long ago schooled. Fifty years after Pynchon published V. (1963), we have come full circle. For in its effort to precisely date its fictive universe through cultural signifiers and in its oblique exploration of the immediate aftermath of the terrorist attacks, Bleeding Edge recalls another great $9 / 11$ novel, perhaps the very first and the very best in that now-crowded genre, William Gibson's Pattern Recognition (2003). Bleeding Edge also recalls the science fiction of Neal Stephenson; DeepArcher resembles an early, uncommercialized version of the Metaverse in Stephenson's classic Snow Crash (1992).

Not only has literary history finally caught up with Pynchon, but political history has created an America that, even on the pages of The Grey Lady, reads all too much like a Pynchon novel. While Bleeding Edge has narrative beats that recall The Crying of Lot 49, there are also telling differences. Pynchon's 1966 novel depended for its sense of mystery and menace on invented organizations, drug-fueled trips, secret histories, and alleged violations of the second law of thermodynamics. Nothing so esoteric can be found in these pages, except for the mysterious Montauk Project.

That Edward Snowden should reveal a panoply of surveillance programs with preposterous, Pynchonian names like XKeyscore, Tempora, and PRISM in the same year that Bleeding Edge came out, would, in a saner America, be the cause of great shock. Not so today. Pynchon instead seems almost like a reporter, a reporter sending signals from an America whose dark underground has become, quite simply, our ground, leaving most conventional 
writers looking less in touch than ever before. Fortunately, Pynchon has stayed in touch, himself an incorruptible still point in American literary life, and when we emerge out the other end of these dark times, we'll partly have him — and the small miracle of his artistry - to thank for keeping us focused on what really matters. 